\title{
KONSEP METODE HISTORICAL COST VERSUS GENERAL PRICE LEVEL ACCOUNTING DALAM PENYUSUNAN LAPORAN KEUANGAN
}

\author{
${ }^{1)}$ Yanna Eka Pratiwi \\ ${ }^{2)}$ Siwidyah Desi Lastianti \\ Fakultas Ekonomi, Universitas Merdeka Surabaya
}

\begin{abstract}
Abstrak
Laporan keuangan merupakan hal sangat penting bagi sebuah perusahaan. Laporan keuangan haruslah relevan dan disajikan dengan akurat, karena informasi-informasi yang terdapat pada laporan keuangan akan digunakan oleh pihak-pihak yang berkepentingan untuk pengambilan keputusan yang berkaitan dengan perusahaan tersebut. Tulisan ini membahas tentang bagaiman perbedaan laporan keuangan yang disusun berdasarkan konsep akuntansi biaya historis (historical cost accounting) dan berdasarkan General Price Level Accounting (GPLA). Berdasarkan literature review, penelitian ini menunjukkan bahwa laporan keuangan yang menggunakan metode General Price Level Accounting lebih interpretatif dan relevan, meskipun masih ada masalah tentang cara dan alat untuk menerapkan metode General Price Level Accounting.
\end{abstract}

Kata kunci: historical cost, general price level accounting, laporan keuangan

\section{Pendahuluan}

Secara umum laporan keuangan disusun berdasarkan nilai historis (Historical Cost Accounting). Dengan prinsip ini laporan keuangan disusun menggunakan harga-harga yang timbul dari transaksi. Sebagai alat pengukur/pertukaran didalam perekonomian digunakan satuan unit moneter. Kondisi inflasi menyebabkan satuan unit moneter menjadi tidak stabil. Sehingga penyusunan laporan keuangan berdasarkan nilai historis tidak mencerminkan adanya perubahan daya beli. Hal tersebut berarti bahwa dalam kondisi tertentu laba atau rugi yang dihasilkan oleh akuntansi atas dasar nilai historis tidak menggambarkan perubahan status ekonomik perusahaan yang sesungguhnya (Suwardjono 2005:359) dan perubahan harga (turunnya daya beli uang) mengakibatkan laporan keuangan yang didasarkan pada prinsip nilai historis 
tidak dapat menghasilkan informasi yang sesuai dengan daya beli yang ada, sehingga akuntansi konvensional perlu dilengkapi data daya beli dengan cara yang layak.

Berkaitan dengan hal tersebut di atas laporan keuangan yang disusun dengan menggunakan metode General Price Level Accounting lebih interpretatif dan relevan daripada laporan keuangan yang disusun dengan menggunakan metode Historical Cost Accounting bila diterapkan pada masa ini.

\section{Pembahasan}

\section{Konsep Biaya Historis (Historical Cost-HC)}

Telah lebih dari satu decade, para akuntan telah menggunakan metode $\mathrm{HC}$ sebagai dasar untuk mengukur, mencatat dan melaporkan aktivitas yang berhubungan dengan ekonomi. Metode HC adalah metode yang berlaku umum dalam akuntansi, yang digunakan dalam laporan keuangan utama, berdasarkan pada pengukuran biaya historis tanpa adanya penyajian kembali (restatement), dimana masing-masing memiliki daya beli yang sama. Metode HC memberi kita informasi tentang pengaruh penggunaan metode $\mathrm{HC}$ terhadap rasio profitabilitas, rasio likuiditas, dan rasio perputaran asset. Dalam metode ini, kecenderungan proporsional terlihat dalam analisis EPS. Sedangkan semua rasio yang lainnya menunjukkan kecenderungan yang sama, namun kurang sebanding. Berdasarkan hasil analisis Strouhal (2015), dampak penggunaan metode $\mathrm{HC}$ terhadap berbagai rasio keuangan digambarkan pada Gambar 1.

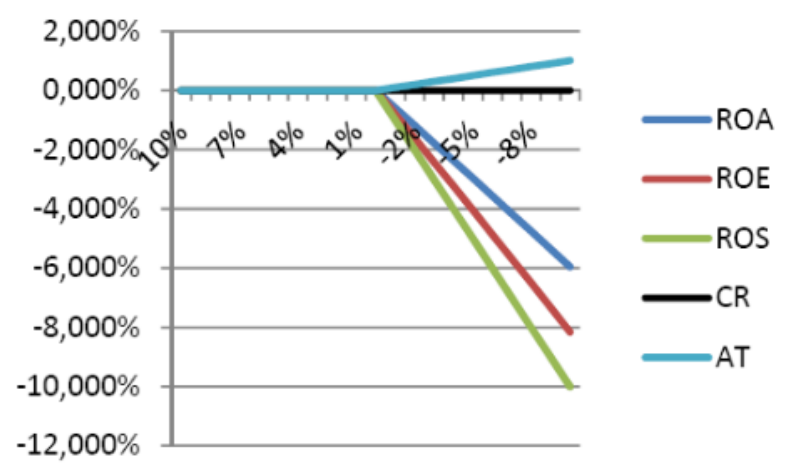

Gambar 1. Model Biaya Historis dan Rasio Keuangan 
Perusahaan yang memilih menyajikan laporan keuangan komprehensif berdasarkan metode HC harus menyajikan kembali persediaan, property, pabrik, dan peralatan, harga pokok penjualan, depresiasi, deplesi, dan biaya amortisasi dan pengurangan jumlah biaya historis persediaan dalam nilai yang konstan yang ditunjukkan oleh tingkat rata-rata selama tahun fiscal indeks harga konsumen untuk semua konsumen (SFAS No. 33).

\section{Konsep General Price Level Accounting}

Masalah akuntansi yang berhubungan dengan perubahan harga pertama kali disajikan secara sistematis dalam artikel Effects of inflation on German Accounting (Sweeney 1927:180-191). Sweney mengemukakan konsep dan prosedur untuk General Purchasing Power Accounting di Amerika. Gagasan dasar dari General Purchasing Power Accounting tidak berubah sampai sekarang, hanya mengalami perkembangan saja (Paton dan Littleton 1940: XV). Gagasan ini timbul dari pentingnya kualitas informasi yang disediakan oleh akuntan untuk manajemen dan para pemakai informasi keuangan lainnya. Bagi manajemen informasi keuangan bermanfaat untuk mengetahui alokasi sumber dana perusahaan dan untuk mengevaluasi kegiatan yang telah dilaksanakan, sehinga informasi ini dapat digunakan manajemen untuk membuat keputusan yang akan datang. Masalah-masalah yang timbul dalam menerapkan konsep General Price Level Accounting adalah: penyusunan laporan keuangan pada tahun tertentu (date), penggunaan indeks (indeks) dan masalah penggolongan pos moneter dan pos non moneter (Rosenfield 1981: 116). Penyusunan laporan keuangan pada tahun berjalan (date). Informasi untuk tahun yang sedang berjalan harus disajikan dalam suatu batas kemampuan daya beli umum pada tahun yang sedang berjalan pula. Untuk mengatasi masalah ini, maka konsep General Price Level Accounting perlu dibatasi dengan tingkat kemampuan daya beli umum di masa lampau dengan menggunakan tahun dasar. 


\section{Kontroversi Penggunaan General Price Level Accounting dalam Penyusunan Laporan Keuangan.}

Kontroversi yang berkaitan dengan kerelevanan General Price Level Acconting telah dan masih berlangsung hingga saat ini. Sejumlah argumentasi yang mendukung telah dikembangkan (Schroeder \& Clark 1995).

- Pertama, laporan keuangan yang tidak disesuaikan dengan tingkat harga umum atau dengan kata lain disajikan berdasarkan nilai historis tidak mencerminkan perubahan kemampuan atau daya beli (purchasing power) dari bermacam-macam aset dan klaim dalam perusahaan. Sedangkan laporan yang disajikan berdasarkan tingkat harga umum menyajikan data yang mencerminkan purchasing power dari aset dan klaim dalam mata uang tertentu dalam akhir periode.

- Argumentasi kedua menyatakan bahwa Conventional Historical Cost Accounting tidak mengukur pendapatan (income) dengan sewajarnya sebagai hasil matching rupiah dalam laporan laba rugi. Beban-beban yang telah terjadi pada periode sebelumnya dikontrakan dengan pendapatanpendapatan yang umumnya dicerminkan dalam nilai rupiah tertentu pada saat ini. General Price Level Accounting menyediakan konsep matching pendapatan dan beban yang lebih baik karena menggunakan nilai uang konstan (common value).

- Ketiga, General Price Level Accounting relative mudah diterapkan. Hanya sekedar mengganti nilai lama dengan nilai saat ini. General Price Level Accounting mencerminkan konsep terakhir dari General Accepted Accounting Principles. Sebagai akibatnya, dirasa relatif lebih obyektif dan dapat diuji kebenarannya. Karakteristik tersebut yang menyebabkan General Price Level Accounting lebih dapat diterima dibanyak perusahaan disbanding Current Value Accounting.

- Keempat, General Price Level Accounting menyediakan informasi yang relevan bagi manajemen dalam evaluasi dan penggunaanya. Jadi laba dan rugi berdasarkan tingkat harga umum dihasilkan dari penanganan item-item moneter yang merefleksikan respons manajemen terhadap inflasi. 
Pada akhirnya, General Price Level Accounting menyajikan pengaruh inflasi secara umum terhadap laba dan menyediakan hasil investasi yang lebih realistis. Relevansi lebih berkepentingan dengan masa sekarang dan masa mendatang. Karena itu informasi yang didasarkan pada nilai historis dianggap kurang relevan untuk tujuan pengambilan keputusan khususnya dalam kondisi ekonomi yang cenderung mengalami inflasi. Jadi penanganan laba dan rugi untuk aset-aset non moneter tidak diakui dan para pengguna data yang disesuaikan pada tingkat harga umum mungkin mempercayai bahwa perubahan nilai-nilai telah berkorespondensi dengan nilai-nilai saat itu. Ketiga, pengaruh atau akibat adanya inflasi akan berbeda dalam berbagai perusahaan. Perusahaan- perusahaan yang intensif modal akan lebih dipengaruhi oleh inflasi dibanding dengan perusahaan-perusahaan yang dipenuhi dengan aset-aset jangka pendek. Keempat, biaya-biaya diimplementasikan lebih besar dari nilai pokoknya dalam General Pricel Level Accounting dibanding benefitnya.

Beberapa peraturan yang dikeluarkan oleh Financial Accounting Standard Board (FASB) di USA juga masih tidak membeberkan kepastian mengenai perlu tidaknya penggunaan General Price Level Accounting, diantaranya: (1) Statement No. 33 yang mengharuskan beberapa perusahaan tertentu untuk menyajikan informasi tambahan dengan menggunakan General Price Level Accounting dan Current Cost Accounting, (2) Statement No. 82 menyatakan bahwa informasi tambahan dengan General Price Level Accounting dan Current Cost Accounting sebaiknya disajikan tetapi tidak diharuskan (Statement No. 82 untuk mengganti Statement No. 33), (3) Pernyataan Standar Akuntansi Keuangan di Indonesia bahwa informasi tambahan antara lain mengenai pengungkapan pengaruh perubahan harga bersifat tidak mengikat.

\section{KESIMPULAN}

Berdasar dari analisis yang telah disajikan di atas, beberapa hal yang dapat disimpulkan dan yang masih harus mendapat perhatian adalah bahwa meskipun metode General Price Level Accounting lebih interpretatif dan relevan, namun masih 
ada masalah tentang cara dan alat untuk menerapkan metode General Price Level Accounting. Permasalahan tersebut meliputi: cara penyusunan keuangan pada tahun tertentu (date), pengunaan indeks dan masalah penggolongan pos moneter dan pos non moneter. Untuk tujuan tertentu, seperti penilaian aset perusahaan dan penilaian kinerja debitur, maka penyesuaian laporan keuangan berdasarkan nilai historis menjadi tingkat harga umum wajib dilakukan, kecuali dalam periode tertentu terjadi perubahan nilai uang yang sangat luar biasa akibat kondisi darurat atau kebijakan moneter tertentu maka tidak ada alasan yang kuat untuk mengungkapkan informasi yang eksplisit tentang adanya perubahan daya beli uang bahkan dalam bentuk suplemen sekalipun. Penyesuaian ini lebih baik daripada hanya menggunakan harga pasar yang tidak dapat ditelusuri dari mana asalnya.

\section{DAFTAR PUSTAKA}

Cristea, Valentin Gabriel. Accounting Harmonization and Historical Cost Accounting.

FASB. 1984. Financial Reporting and Changing Prices: Elimination Of Certain Disclosures, Statement Of Financial Accounting Conceps No. 82.

Financial Accounting Standards Board. 1979. Statement of Financial Accounting Standards No. 33.

Ikatan Akuntan Indonesia. 2004. Standar Akuntansi Keuangan. Jakarta : Salemba Empat.

Rosenfield, Paul. 1981. A History Of Inflation Accounting, Journal Of Accountancy, September

Rahmawati, Evi. 2006. Support and Againts Historical Cost Accounting: Is It Value Relevance for Decision Making?. Jurnal Akuntansi dan Investasi Vol. 7 No. 1.

Schoeder, Richard G. and Clark, Myrtle. 1995. Accounting Theory: Text \& Reading, New York: John Willy \& Sons. 
Stroul, Jiri. 2015. Historical Cost or Fair Value in Accounting: Impact on Selected Financial Ratios. Journal of Economics, Business and Management, Vol. 3, No. 5.

Suwardjono, 2005. Teori Akuntansi Perekayasaan Pelaporan Keuangan, Yogyakarta:BPFE

Sweeney, Hendry W. 1927. Effects Of Inflation on German Accounting. Jofa.March 